\title{
Size matters: bleaching dynamics of the coral Oculina patagonica
}

\author{
N. Shenkar ${ }^{1, *}$, M. Fine ${ }^{2}$, Y. Loya ${ }^{1}$ \\ ${ }^{1}$ Department of Zoology, The George S. Wise Faculty of Life Sciences and the Porter Super-Center for Ecological \\ and Environmental Studies, Tel-Aviv University, Tel Aviv 69978, Israel \\ ${ }^{2}$ The Leon Recanati Institute for Maritime Studies, University of Haifa, Mount Carmel, Haifa 31905, Israel
}

\begin{abstract}
A 2-yr continuous photographic monitoring of a tagged population of the encrusting coral Oculina patagonica in the Mediterranean was conducted to study intra-colonial bleaching dynamics and the relationship between bleaching, mortality, and colony size. Surveys of non-tagged colonies showed that during the peak bleaching season (August, sea surface temperature $=31^{\circ} \mathrm{C}$ ), non-bleached colonies were frequently found to be small colonies averaging $4.6 \pm 2.3 \mathrm{~cm}$ in diameter. Within tagged colonies, percent bleached surface area was correlated to water temperature. In colonies that underwent bleaching, the perimeter of the colony was affected first, and, as water temperatures increased, bleaching progressed toward the colony center. During the summer months, partial mortality occurred in the perimeter region of bleached colonies in $22 \%$ of the tagged colonies and $25 \%$ of the tagged colonies died; $40 \%$ of the colonies that died belonged to the largest size group. This partial mortality caused an average decline of $46 \pm 27 \%$ in the average colony size, resulting in a shift to a smaller size group within the monitored population. Since in this species, colonies as small as $2 \mathrm{~cm}$ in diameter are reproductive, bleaching may have a less significant effect on the reproductive fitness of the small size groups in the population. The high mortality of large colonies, high survivorship of the small colonies, and the decline in colony size, due to partial mortality, suggest that, in the case of bleaching in populations of $O$. patagonica, small colony size is advantageous.
\end{abstract}

KEY WORDS: Coral bleaching $\cdot$ Mediterranean Sea $\cdot$ Population dynamics $\cdot$ Oculina patagonica

\section{INTRODUCTION}

Coral bleaching, the whitening of corals due to loss of their symbiotic algae (zooxanthellae) and/or their pigments (Hoegh-Guldberg \& Smith 1989, Glynn 1993, Brown 1997), has affected extensive reef areas around the world (Hoegh-Guldberg 1999). Bleaching is deleterious for corals, resulting in reduced growth rates (Goreau \& MacFarlane 1990), suppression of sexual reproduction (Szmant \& Gassman 1990, Fine et al. 2001), impaired healing following damage (Meesters \& Bak 1993), increased susceptibility to disease (Harvell et al. 1999), and, occasionally, mass mortality (Wilkinson 1999, Glynn et al. 2001, Loya et al. 2001). Mortality in corals is generally size specific, and rates of whole- colony mortality decrease as the size of the colony increases (Connell 1973, Sakai 1998). However, mortality following bleaching events is believed to be independent of colony size (Baird \& Marshall 2002). Nevertheless, field evidence indicates that mortality rates of coral recruits are unaffected by bleaching (Mumby 1999) and show high recovery by recently settled juveniles compared with adults (Edwards et al. 2001). Moreover, both experimental and theoretical works predict that large size may actually be a disadvantage when corals are exposed to thermal stress (Nakamura \& Van Woesik 2001). Loya et al. (2001) reported that small colonies of acroporid corals had higher survivorship than large colonies in the same habitat, following a mass bleaching event in Okinawa, 
Japan. This phenomenon reoccurred following a bleaching event at the same site 3 yr later, when small colonies of Acropora were least affected (Bena \& Van Woesik 2004). Similar results were found following a bleaching event in the Java Sea, when the smallest mushroom corals (fungiids) were the least affected (Hoeksema 1991). Thus, the accumulating evidence raises the question of a possible relationship between colony size and bleaching.

While large-scale bleaching patterns of coral reefs have been studied extensively (Hoegh-Guldberg 1999), little is known about within-colony bleaching patterns (spatial distribution of bleached patches over the surface of a colony). The manner in which colonies bleach is considered species specific (Lasker et al. 1984, Gates 1990). For example, within the Fungiidae, some species were affected over their whole upper surface during a bleaching event, while other species showed a mosaic pattern (Hoeksema 1991). In Agaricia spp. the ridges of the colonies appeared white, while Montastrea annularis colonies had a 'blotchy' appearance, and in Porites porites bleached tissue was restricted to 1 or 2 branches of the top of the colony (Gates 1990). Lasker et al. (1984) described a similar bleaching pattern for the hydroids Millepora alcicornis and $M$. complanata, where colonies first whitened at their tips and the bleached area then extended toward the colony base. Brown et al. (2000) reported intercolonial bleaching patterns in Goniastrea aspera and explained it by differential exposure to solar radiation between east- and west-facing surfaces.

Every summer since 1996, 80 to $90 \%$ of the colonies of the encrusting coral Oculina patagonica undergo bleaching in the Mediterranean Sea, off the coast of Israel (Israely et al. 2001). This occurs when surface seawater temperatures (SST) rise over $26^{\circ} \mathrm{C}$ to a maximum of 30 to $31^{\circ} \mathrm{C}$. It was shown that the causative agent for bleaching in this coral was the bacterium Vibrio shiloi (Kushmaro et al. 1996, 1997) and that seawater temperature is a contributing factor (Rosenberg $\&$ Ben-Haim 2002). In contrast to reports of post-bleaching mass mortality from other regions, most of the $O$. patagonica colonies recover during the winter months. Bleaching then re-occurs as the water temperatures rise the following summer (Kushmaro et al. 1998, Fine et al. 2001). The repeated and high incidence of these bleaching events in $O$. patagonica colonies along the Israeli Mediterranean shore makes this coral a model organism for studying the dynamics of bleaching at both population and individual colony levels. This study is the first to conduct continuous monitoring of the same coral population during 2 consecutive bleaching events in order to examine within-colony bleaching patterns and to ascertain the relationship between bleaching, colony size, and partial mortality.

\section{MATERIALS AND METHODS}

The study was performed from 2000 to 2003 at SdotYam (Mediterranean coast of Israel: $32^{\circ} 29.77^{\prime} \mathrm{N}$, $34^{\circ} 53.23^{\prime} \mathrm{E}$ ) along the 'vermetid reefs' at a depth range of 3 to $6 \mathrm{~m}$. Observations were performed by SCUBA diving. Ambient seawater temperatures were obtained using an Onset Stow Away data-logger placed at the study site at a depth of $1.5 \mathrm{~m}$.

Survey. During August and November 2001 and August and September 2002, bleaching surveys were conducted at Sdot-Yam. A defined area of $500 \mathrm{~m}^{2}$ was examined extensively by SCUBA diving. The diameter of each Oculina patagonica colony observed in the study area was measured to the nearest millimeter using a ruler, and the percentage of the bleached surface area was estimated visually.

Photographic monitoring. A total of 62 colonies of Oculina patagonica were tagged (31 in December 2000 and 31 in October 2001) at the study site. During the research all examined colonies were photographed monthly using a Nikonos-V camera or a digital Sony DSC P-9 camera. The photographs were transferred to JPEG format to enable further analysis. Bleaching progression (increase in the colony bleached surface area) was examined using the PHOTOSHOP 7 (Adobe) program by laying several consecutive photographs one on top of another. Total colony area and bleached surface area were measured using the INSPECTOR 2.1 (Matrox Electronic Systems) program. This allowed the calculation of bleaching percentage and progression.

In order to examine whether colony size plays a role in bleaching, the tagged colonies were divided at the beginning of the monitoring period into 3 size classes, with respect to their maximal live surface area (MLSA) as follows: small (MLSA $<16 \mathrm{~cm}^{2}$ ), medium (MLSA $>16 \mathrm{~cm}^{2}$ and $<60 \mathrm{~cm}^{2}$ ), and large (MLSA $\left.>60 \mathrm{~cm}^{2}\right)$.

Zooxanthella density and chlorophyll measurements. In order to ascertain whether the within-colony bleaching pattern is due to a possible difference between the initial density of zooxanthellae and the chlorophyll a concentration in the colony center versus its margins, equal-sized core samples $(1 \mathrm{~cm}$ diameter and 2 to $3 \mathrm{~mm}$ thick) from the center and the perimeter were sampled (May 2003) from 8 randomly selected healthy colonies. Coral tissue was removed from the skeleton using a jet of re-circulated, $0.45 \mu \mathrm{m}$ filtered seawater (FSW) using a WaterPik (Teledyne, Johannes $\&$ Wiebe 1970) and centrifuged at $4500 \times g$ for $20 \mathrm{~min}$ in 50-ml tubes. In order to separate host tissue from zooxanthellae, the liquid extract was discarded and the pellet was re-suspended in $1 \mathrm{ml} \mathrm{FSW,} \mathrm{homo-}$ genized, and transferred to 1.5-ml Eppendorf tubes. Following centrifugation at $20000 \times g$ for $10 \mathrm{~min}$, the liquid extract was discarded and the pellet was re- 
suspended in $1 \mathrm{ml}$ FSW. This step was repeated twice in order to obtain a clean sample. Density of zooxanthellae in each sample was determined from counts of 3 sub-samples (10 $\mu$ l each), which were viewed using an improved Neubauer hemocytometer (Weber). Counts were normalized to coral surface area.

To quantify chlorophyll a concentration the pellet containing the zooxanthellae was further assayed by extraction in $1 \mathrm{ml}$ of chilled $90 \%$ acetone overnight. The extracted chlorophyll was quantified spectrophotometrically, and the chlorophyll a concentration was calculated using the equations of Jeffery \& Humphrey (1975) and normalized to coral surface area.

Statistical analysis. All statistical analyses were carried out using Statistica 6.1. The data were tested for normality and homogeneity of variances, when required arcsine transformations were obtained. Fisher's LSD (least significant differences) tests were used as post hoc comparisons when significant differences were detected using ANOVAs (analyses of variance). Results are presented as averages ( \pm standard deviations) throughout the text.

\section{RESULTS}

\section{Seasonal bleaching of Oculina patagonica colonies in the Mediterranean Sea}

A correlation $\left(\mathrm{r}^{2}=0.49, \mathrm{p}<0.01\right)$ between seawater temperature and percent bleached surface area of the coral Oculina patagonica (Fig. 1) was found. Monthly photographs revealed that the percentage of bleached surface area of the tagged colonies increased rapidly in the summer following a rise in seawater temperatures. Colony bleached surface area reached a maximum average of $42 \pm 20 \%$ in August 2001 and $30 \pm$
$22 \%$ in August 2002, when water temperature reached $30^{\circ} \mathrm{C}$ (Fig. 1). As water temperature decreased during the winter months, the bleached colony surface area decreased, reaching a minimum of $4.0 \pm 9 \%$ in April 2001 and May 2002, when water temperature reached 20 to $22^{\circ} \mathrm{C}$.

\section{Bleaching progression within colonies of Oculina patagonica}

Monthly monitoring revealed that bleaching appeared first at the perimeter of the colony. As the temperature continued to rise, bleaching progressed toward the center of the colony, resulting in the center being the last area within the colony to undergo bleaching (Fig. 2). This phenomenon was observed in $94 \%$ of the tagged colonies.

\section{Zooxanthella density and chlorophyll concentrations}

No significant difference in zooxanthella density and chlorophyll concentration $(\mathrm{n}=8$ Wilcoxon matched pairs test, $\mathrm{p}>0.05$ ) was found between the edge and center of non-bleached colonies. Zooxanthella density at the colony edge was $6.24 \pm 1.8 \times 10^{6}$ cells $\mathrm{cm}^{-2}$ and chlorophyll concentration was $16.76 \pm 5.02 \mu \mathrm{g}$ chl a $\mathrm{cm}^{-2}$ versus $5.8 \pm 2.2 \times 10^{6}$ cells $\mathrm{cm}^{-2}$ and $16.67 \pm 6.7 \mu \mathrm{g}$ chl a $\mathrm{cm}^{-2}$, respectively, at the colony center.

\section{Mortality, bleaching, and colony size}

During the summer months partial mortality of the perimeter occurred in $22 \%$ of the tagged colonies $(\mathrm{n}=$ 62 colonies). This resulted in an average decline of $46 \pm$

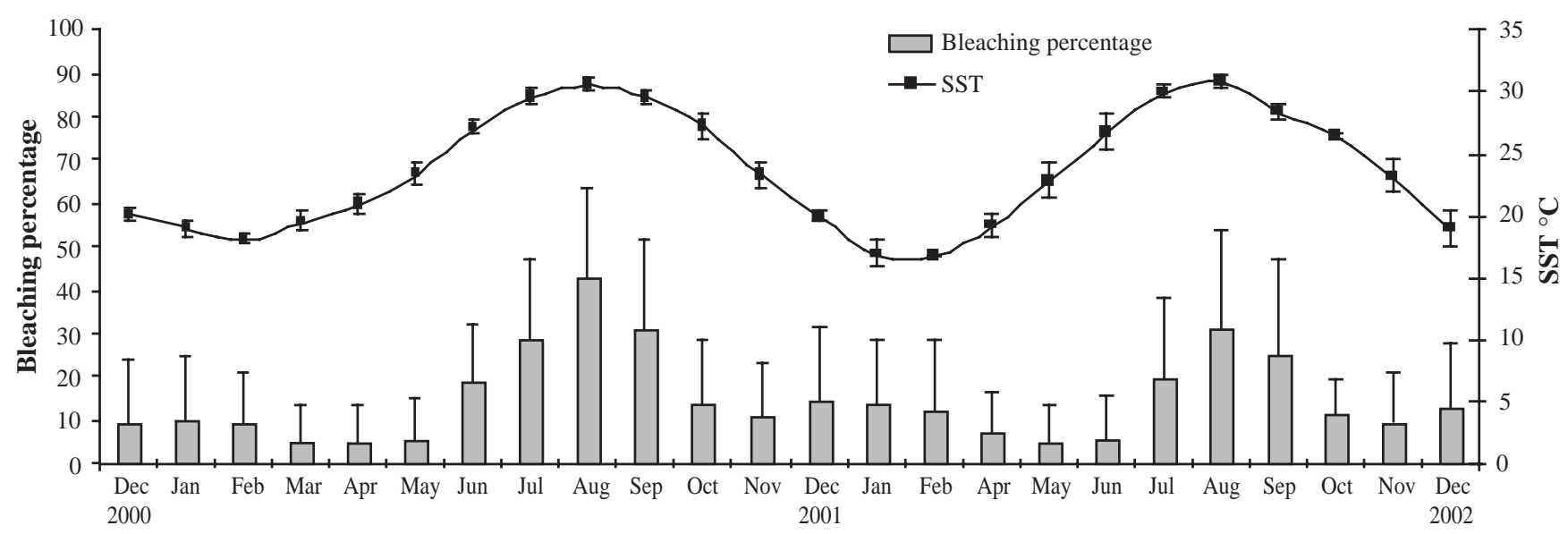

Fig. 1. Oculina patagonica. Mean percentage $( \pm \mathrm{SD})$ of bleached surface area relative to whole colony surface from December 2000 to December 2002 (SST: sea surface temperature) 


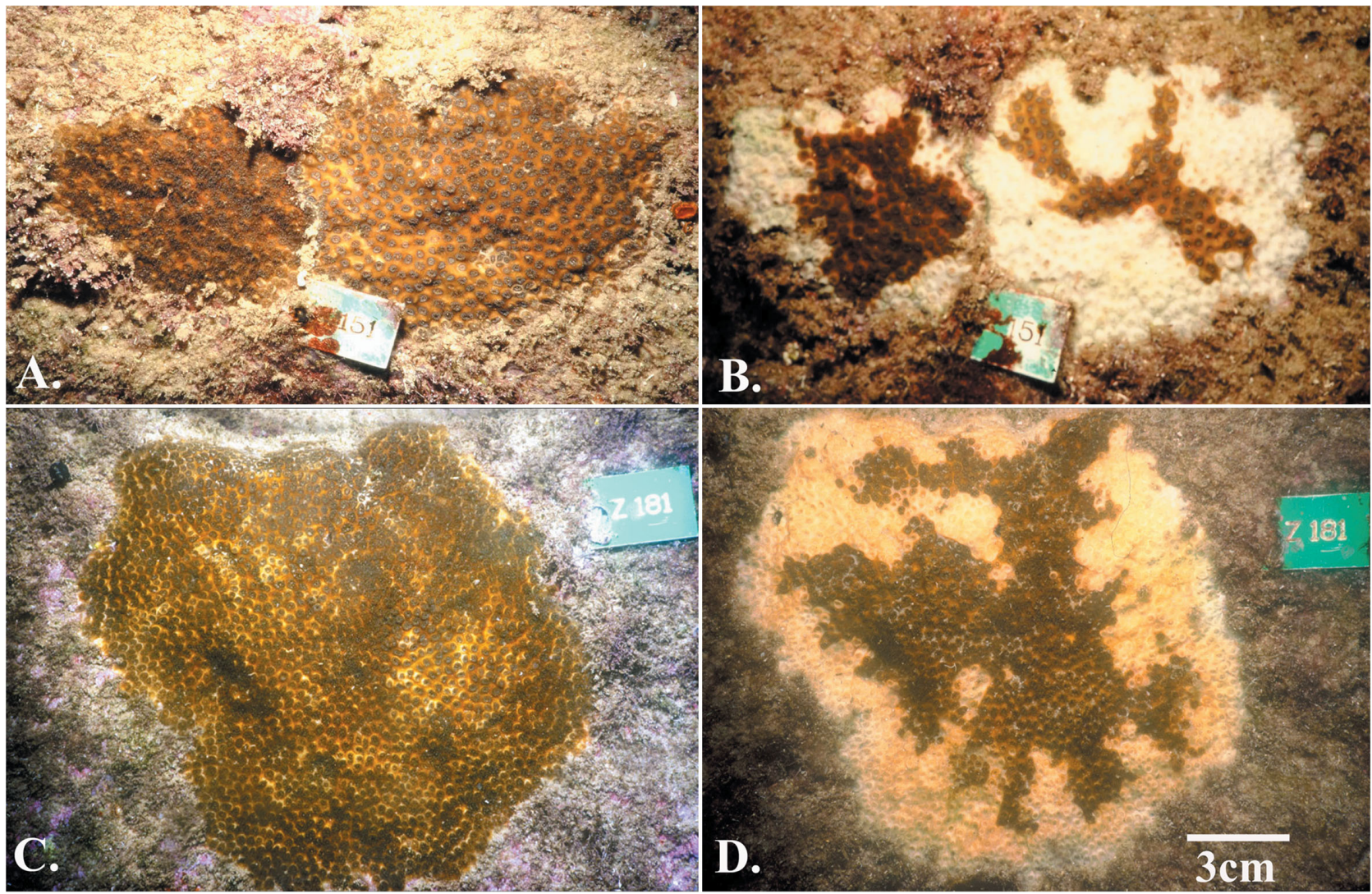

Fig. 2. Oculina patagonica. Bleaching progression from colony perimeter toward colony center. (A,B) Two neighboring colonies (1 of which is no. 151) in May and June 2002. (C,D) Colony no. 181 in June and July 2001

$27 \%$ of the colony live surface area, causing colonies belonging to the large size group (as measured by maximal live surface area) to be shifted to a smaller size group within the monitored population. During the bleaching season no growth was recorded in any of the tagged colonies. Concomitant with the decrease in water temperatures, the living surface area of the colonies increased, until the water temperature increased again (Fig. 3).

During the research period $25 \%$ of the 62 tagged colonies died. Although all dead colonies had undergone bleaching at some point during the study, no significant difference was found in bleaching percentage between the group of colonies that died and those that survived (repeated-measures ANOVA, transformed data, $p>0.05$ ). Of the corals that died, over half died during July $(2001: \mathrm{n}=6 ; 2002: \mathrm{n}=4)$, when most of the colonies were bleached.

Both colonies that died and colonies with partial mortality in their perimeter region were significantly larger (ANOVA, followed by Fisher's LSD, $p<0.05$ ) compared to the rest of the tagged colonies (Fig. 4). Together the 'dead colonies' group and the corals of the 'coral perimeter mortality' group had an average live surface area of $65 \pm 42 \mathrm{~cm}^{2}$ versus a live surface area of $40 \pm 31 \mathrm{~cm}^{2}$ for the 'intact group' (Fig. 4).

During the peak bleaching season, in August, when seawater temperature reached $30^{\circ} \mathrm{C}$, we could still observe colonies that did not bleach. Surveys revealed that the colonies that did not bleach were significantly smaller ( $t$-test, $\mathrm{p}<0.0001)$, with an average colony diameter of $4.62 \pm 2.3 \mathrm{~cm}(\mathrm{n}=243)$, than colonies that underwent bleaching (average colony diameter $7.75 \pm$ $4.5 \mathrm{~cm}, \mathrm{n}=407$, Fig. 5).

In addition, although a significant regression was found between colony diameter and the proportion of colonies that underwent bleaching (Spearman linear regression, $r^{2}=0.96, p<0.05$, Fig. 6), no significant correlation $\left(r^{2}=0.066, p>0.05\right)$ was found between colony size and amount of within-colony bleaching (i.e. percent bleached tissue).

\section{DISCUSSION}

In the present study, we examined differential susceptibility to bleaching and survival following a bleaching event of a tagged population of Oculina patago- 


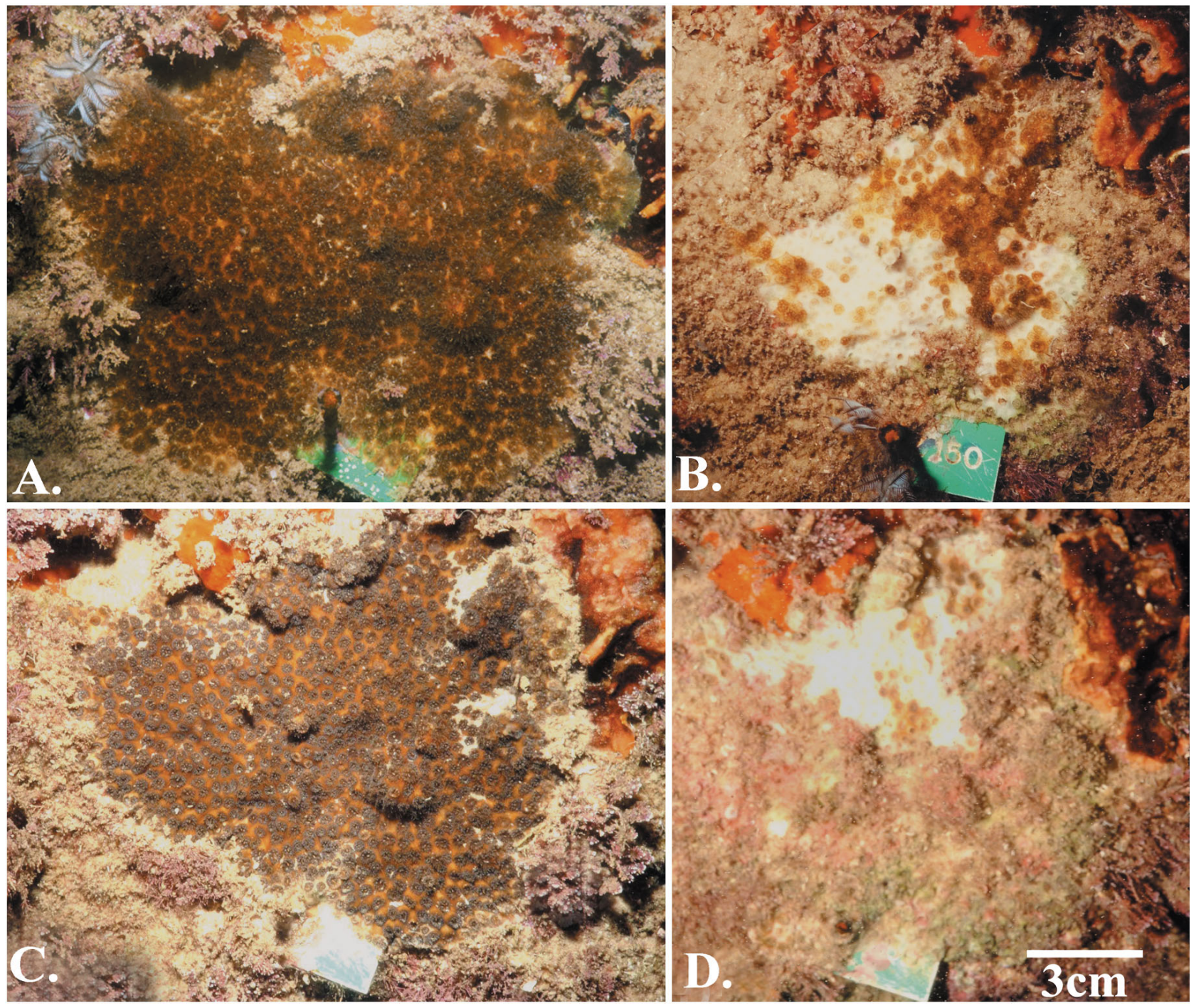

Fig. 3. Oculina patagonica. An example of partial mortality at the perimeter (colony no. 150) in: (A) May 2001 when the live surface area was $133 \mathrm{~cm}^{2}$, (B) following a bleaching event when the live surface area decreased to $57 \mathrm{~cm}^{2}$ in August 2001, (C) as the water temperature dropped the live surface area reached $125 \mathrm{~cm}^{2}$ in May 2002. (D) As the water temperature rose again the live surface area decreased to $20 \mathrm{~cm}^{2}$ in August 2002

nica. Some colonies within that population are apparently more susceptible to bleaching than others, and some survive bleaching better than others. We examined both inter-colony bleaching variations and intracolonial bleaching patterns. Kushmaro et al. (1998) showed a significant correlation between seawater temperature and the percentage of bleached colonies in a population of $O$. patagonica (a colony was considered 'bleached' even if it showed a low percentage of bleaching). In the present study we also showed a significant correlation between water temperature and the within-colony bleaching percentage (Fig. 1). In June, when water temperature reaches $26^{\circ} \mathrm{C}$, the first bleaching spots appear. Monthly monitoring revealed that bleaching first appears at the perimeter of the colony and progresses toward the center of the colony (Fig. 2). As no differences in zooxanthella density, or their chlorophyll content, were found between the perimeter and center of non-bleached colonies, the early onset of bleaching in distal areas of the colony is intriguing. It is possible that the bacterial agent, Vibrio shiloi, infects the colony from the substrate near the coral colony and not from the water column. Supporting this hypothesis are the descriptions of other coral diseases, e.g. white-band and white plague, in which the diseases frequently started at the base of the colony, the point of contact with the substrate (Gladfelter 1982, Nugues 2002).

Partial mortality is a well-known phenomenon in colonial stony corals (Bythell et al. 1993, Meesters et al. 


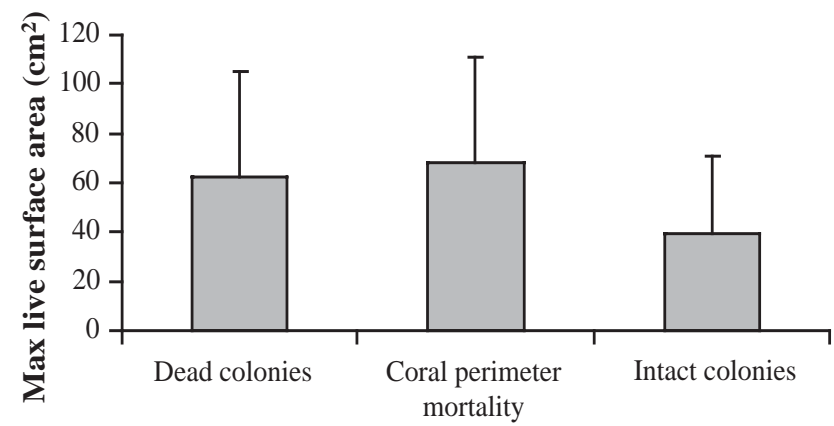

Fig. 4. Oculina patagonica. Comparison of mean maximal live surface area $( \pm \mathrm{SD})$, measured during the research period, of the colonies that died (dead colonies, $\mathrm{n}=16$ ), the colonies that underwent partial mortality of the perimeter region (perimeter mortality, $\mathrm{n}=14$ ), and the rest of the colonies (intact colonies, $\mathrm{n}=29 ; 3$ colonies were discarded due to technical problems)

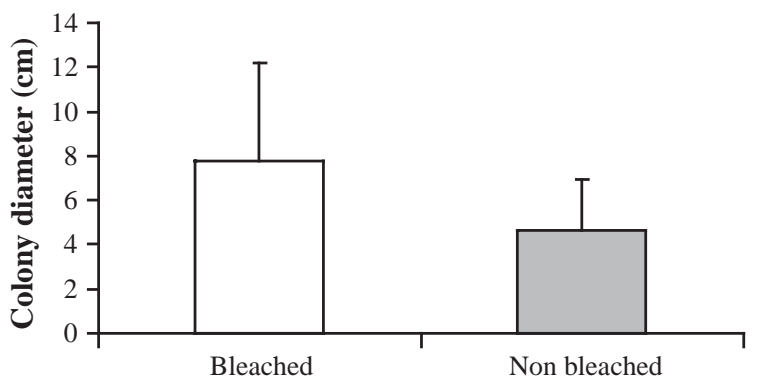

Fig. 5. Oculina patagonica. Comparison of mean colony diameter $( \pm \mathrm{SD})$ between colonies that underwent bleaching $(n=407)$ and colonies that did not bleach $(n=243)$

1996, 1997, Bak \& Meesters 1998), causing large colonies to shrink into smaller sizes (Bak \& Meesters 1999). Partial mortality occurs frequently after bleaching events (Fong \& Glynn 2000, Feingold 2001, Baird \& Marshall 2002). Interestingly, in colonies of Oculina patagonica that undergo partial mortality, the lesion progression follows a very similar pattern to that of bleaching, i.e. the perimeter dies first and the lesion progresses towards the center of the colony (Fig. 3); $22 \%$ of the tagged colonies demonstrated partial mortality of the perimeter, resulting in an average decline of $46 \%$ in the average colony size, and a shift to a smaller size group. This may be explained by a longer stress (bleaching) period experienced by polyps in the perimeter as compared with polyps at the colony center, leading to their death. Fine et al. (2002) reported termination of intra-colonial resource translocation toward bleached parts of O. patagonica colonies. It is possible that during bleaching there is a controlled 'blockage' of the unbleached colony section (colony center) from the bleached section (perimeter region). The breakdown of resource flow toward the perimeter polyps may explain their inability to survive during a bleaching event. Thus O. patagonica exhibits seasonal

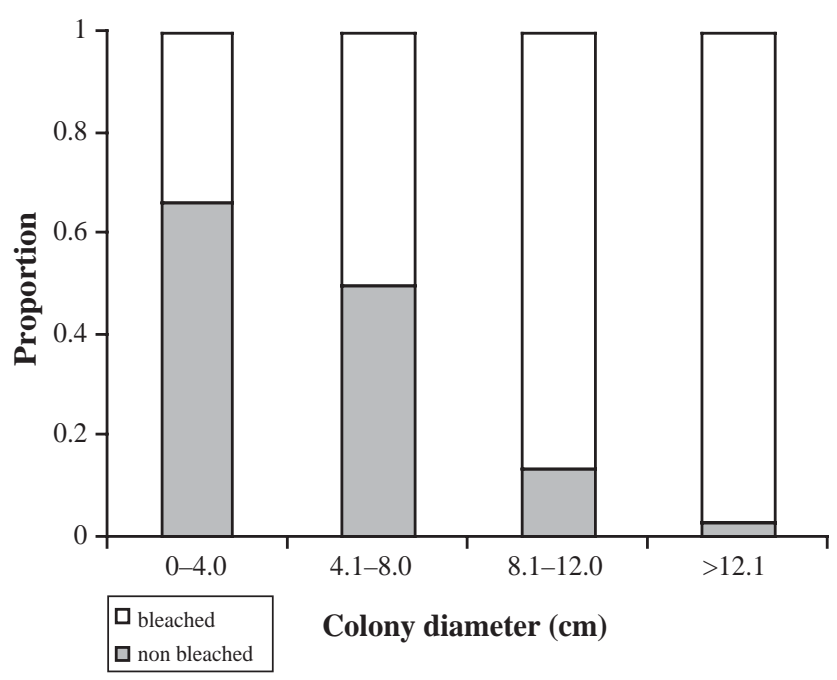

Fig. 6. Oculina patagonica. Proportion of bleached colonies (white) and healthy colonies (gray) according to different size groups $(\mathrm{n}=650)$

size plasticity, i.e. colony 'shrinkage' during summer, followed by re-growth during winter. Consequently, in O. patagonica, colony size cannot always serve as an indication of age, as suggested for Stylophora pistillata (Loya 1976) and Fungia granulosa (Chadwick-Furman et al. 2000), since small colonies might actually be 'old' colonies, exhibiting partial mortality following a bleaching event.

Despite the high recovery rate described for Oculina patagonica in previous studies (Kushmaro et al. 1996), during the present research period, $25 \%$ of the tagged colonies died. Surprisingly, the colonies that died were the large colonies (Fig. 4), which usually have a higher survivorship probability than smaller colonies under different stressors (Hughes \& Jackson 1980, Johnson et al. 1995). Moreover, colonies in which partial mortality of the perimeter region took place were significantly larger than the rest of the tagged colonies (Fig. 4). Periodical surveys showed that during the peak bleaching season, when water temperature reaches $31^{\circ} \mathrm{C}$, the healthy colonies were small colonies, averaging $4.62 \pm$ $2.3 \mathrm{~cm}$ in diameter (Fig. 5). This may be a result of a higher probability of the large colonies to be infected by Vibrio shiloi, the causative agent of bleaching in O. patagonica (Kushmaro et al. 1996). Similar results were described by Nugues (2002) after an outbreak of the 'plague' coral disease in the Caribbean, in which small coral colonies were more likely to escape infections then large colonies. Loya et al. (2001) suggested that the higher survivorship of small Acropora colonies following a bleaching event may be linked to their juvenile morphology. Their hypothesis is based on Patterson's (1992) theoretical work suggesting that under a unit-flow regime flat colonies should have a higher 
mass transfer than branched colonies. Therefore, small Acropora colonies, which often remain relatively flat up to 1-1.5 yr of age, should have a higher mass transfer than large, branching colonies. Since bleaching conditions (high SSTs, high solar radiation) cause the accumulation of superoxides and other oxygen radicals in coral colonies (Lesser 1997, Jones et al. 1998), the efficient reduction or removal of these by-products will be essential to ensure colony survival. Indeed, recent studies have shown how stronger water flow, which increases mass transfer, has a positive effect on bleached corals (Nakamura \& Van Woesik 2001, Nakamura et al. 2003). In addition, Nakamura \& Van Woesik (2001) showed that based on Newton's law of viscosity and Reynolds number, which relates to the dimensional characteristics of the organism, the mass transfer or rates of diffusion within a given surface area to and from small organisms is more rapid than to and from large organisms. According to this theory, small O. patagonica colonies will have an advantage over large colonies, since they can eliminate toxins more efficiently through diffusion. Metabolic toxins, super oxides, other free radicals (Lesser 1997, Jones et al. 1998, Downs et al. 2002), and bacterial toxins (Banin et al. 2001) may cause damage to the symbiotic algae and eventually lead to colony mortality, as occurred in the large $O$. patagonica colonies following a bleaching event.

Bak \& Meesters (1999) claim that global change will have an impact on recruits and the smallest size classes, causing an increase in mean colony size and a shift in the coral size-frequency distribution toward the larger size classes. In the case of bleaching of Oculina patagonica, however, the opposite trend exists. The current results of high mortality of large colonies, the decline in colony size due to partial mortality, and the high survivorship of the small colonies all suggest that small colony size is advantageous. This leads to the prediction that in a population that undergoes repeated bleaching events, the colony size distribution is expected to be skewed toward a smaller size, with an average colony size smaller than in an undisturbed population. Furthermore, since in this species colonies as small as $2 \mathrm{~cm}$ in diameter are reproductive (Fine et al. 2001), bleaching may have a less significant effect on the reproductive fitness of the small size groups in the population.

Recent field evidence from coral reefs around the world indicates that, following bleaching events, there is a higher survivorship and resilience of small colonies and recruits (Mumby 1999, Normile 2000, Loya et al. 2001, Bena \& Van Woesik 2004). This may indicate that coral reefs might be more resilient than previously thought. However, considering the predicted increase in frequency and severity of bleaching events (Hoegh-
Guldberg 1999), the ability of corals to mature, recover, and reproduce is still uncertain. Further research is essential in order to clarify the relationship between colony size and bleaching, as well as the ability of small colonies to thrive over time following reoccurring bleaching events.

Acknowledgements. We are grateful to R. Tzadok, Y. Aluma, and N. Sokolover for their technical help in the field, and to E. Kramarsky-Winter and N. Paz for editorial assistance. We are especially indebted to Ruth Gates for her inspiring ideas and constructive suggestions. This research was supported by the Israel Science Foundation (ISF) and the Raynor Chair for Environmental Conservation Research to Y.L.

\section{LITERATURE CITED}

Baird AH, Marshall PA (2002) Mortality, growth and reproduction in scleractinian corals following bleaching on the Great Barrier Reef. Mar Ecol Prog Ser 237:133-141

Bak RPM, Meesters EH (1998) Coral population structure: the hidden information of colony size-frequency distributions. Mar Ecol Prog Ser 162:301-306

Bak RPM, Meesters EH (1999) Population structure as a response of coral communities to global change. Am Zool 39(1):56-65

Banin E, Khare SK, Naider F, Rosenberg E (2001) Proline-rich peptide from the coral pathogen Vibrio shiloi that inhibits photosynthesis of zooxanthellae. Appl Environ Microbiol 67(4):1536-1541

Bena C, Van Woesik R (2004) The impact of two bleaching events on the survival of small coral colonies (Okinawa, Japan). Bull Mar Sci 75:115-125

Brown BE (1997) Coral bleaching: causes and consequences. Coral Reefs 16:129-138

Brown BE, Dunne RP, Goodson MS, Douglas AE (2000) Bleaching patterns in reef corals. Nature 404:142-143

Bythell JC, Bythell M, Gladfelter EH (1993) Initial results of a long-term coral reef monitoring program: impact of hurricane Hugo at Buck Island Reef National Monument, St. Croix, U.S. Virgin Islands. J Exp Mar Biol Ecol 172: 171-183

Chadwick-Furman NE, Goffredo S, Loya Y (2000) Growth and population dynamic model of the reef coral Fungia granulosa Klunzinger, 1879 at Eilat, northern Red Sea. J Exp Mar Biol Ecol 249(2):199-218

Connell JH (1973) Population ecology of reef-building corals. In: Jones OA, Endean R (eds) Biology and geology of coral reefs. Academic Press, London, p 271-324

Downs CA, Fauth JE, Halas JC, Dustan P, Bemiss J, Woodley CM (2002) Oxidative stress and seasonal coral bleaching. Free Radic Biol Med 33(4):533-543

Edwards AJ, Clark S, Zahir H, Rajasuriya A, Naseer A, Rubens J (2001) Coral bleaching and mortality on artificial and natural reefs in Maldives in 1998, sea surface temperature anomalies and initial recovery. Mar Pollut Bull 42(1): $7-15$

Feingold JS (2001) Responses of three coral communities to the 1997-98 El Niño-Southern Oscillation: Galapagos Islands, Ecuador. Bull Mar Sci 69(1):61-77

Fine M, Zibrowius H, Loya Y (2001) Oculina patagonica: a non-lessepsian scleractinian coral invading the Mediterranean Sea. Mar Biol 138:1195-1203

Fine M, Oren U, Loya Y (2002) Bleaching effect on regenera- 
tion and resource translocation in the coral Oculina patagonica. Mar Ecol Prog Ser 234:119-125

Fong P, Glynn PW (2000) A regional model to predict coral population dynamics in response to El Niño-Southern Oscillation. Ecol Appl 10(3):842-854

Gates RD (1990) Seawater temperature and sublethal coral bleaching in Jamaica. Coral Reefs 8(4):193-197

Gladfelter WB (1982) White band disease in Acropora palmate: implications for the structure and growth of shallow reefs. Bull Mar Sci 32:639-643

Glynn PW (1993) Coral reef bleaching ecological perspectives. Coral Reefs 12(1):1-17

Glynn PW, Maté JL, Baker AC, Calderón MO (2001) Coral bleaching and mortality in Panama and Ecuador during the 1997-1998 El Niño-Southern Oscillation event: spatial/temporal patterns and comparisons with the 19821983 event. Bull Mar Sci 69:79-109

Goreau TJ, MacFarlane AH (1990) Reduced growth rate of Montastrea annularis following the 1987-1988 coralbleaching event. Coral Reefs 8:211-215

Harvell CD, Kim K, Burkholder JM, Colwell RR and 9 others (1999) Emerging marine diseases-climate links and anthropogenic factors. Science 285:1505-1510

Hoegh-Guldberg O (1999) Climate change, coral bleaching and the future of the world's coral reefs. Mar Freshw Res 50:839-866

Hoegh-Guldberg O, Smith GJ (1989) The effect of sudden changes in temperature, irradiance and salinity on the population density and export of zooxanthellae from the reef corals Stylophora pistillata (Esper, 1797) and Seriatopora hystrix (Dana, 1846). J Exp Mar Biol Ecol 129:279-303

Hoeksema BW (1991) Control of bleaching in mushroom coral populations (Scelactinia, Fungiidae) in the Java SeaStress tolerance and interference by life history strategy. Mar Ecol Prog Ser 74(2/3):225-237

Hughes TP, Jackson JBC (1980) Do corals lie about their age - some demographic consequences of partial mortality, fission and fusion. Science 209(4457):713-715

Israely T, Banin E, Rosenberg E (2001) Growth, differentiation and death of Vibrio shiloi in coral tissue as a function of seawater temperature. Aquat Microb Ecol 24:1-8

Jeffrey SW, Humphrey GF (1975) New spectrophotometric equation for determining chlorophylls $a, b, c_{1}$ and $c_{2}$ in higher plant, algae and natural phytoplankton. Biochem Physiol Pflanz (BPP) 167:191-194

Johannes RE, Wiebe WJ (1970) Method for determination of coral tissue biomass and composition. Limnol Oceanogr 15:579-586

Johnson KG, Budd AF, Stemann TA (1995) Extinction selectivity of neogene Caribbean reef corals. Paleobiology 21:52-73

Jones RJ, Hoegh Guldberg O, Larkum AWD, Schreiber U (1998) Temperature-induced bleaching of corals begins with impairment of the $\mathrm{CO}_{2}$ fixation mechanism in zooxanthellae. Plant Cell Environ 21(12):1219-1230

Kushmaro A, Loya Y, Fine M, Rosenberg E (1996) Bacterial infection and coral bleaching. Nature 380:396

Kushmaro A, Rosenberg E, Fine M, Loya Y (1997) Bleaching

Editorial responsibility: Otto Kinne (Editor-in-Chief), Oldendorf/Luhe, Germany of the coral Oculina patagonica by Vibrio AK-1. Mar Ecol Prog Ser 147:159-165

Kushmaro A, Rosenberg E, Fine M, Ben Haim Y, Loya Y (1998) Effect of temperature on bleaching of the coral Oculina patagonica by Vibrio AK-1. Mar Ecol Prog Ser 171:131-137

Lasker HR, Peters EC, Coffroth MA (1984) Bleaching of reef coelenterates in the San Blas Islands, Panama. Coral Reefs 3:183-190

Lesser MP (1997) Oxidative stress causes coral bleaching during exposure to elevated temperatures. Coral Reefs 16: $187-192$

Loya Y (1976) Red-Sea coral Stylophora pistillata is an rstrategist. Nature 259(5543):478-480

Loya Y, Sakai K, Yamazato K, Nakano Y, Sambali H, Van Woesik R (2001) Coral bleaching: the winners and the losers. Ecol Lett 4:122-131

Meesters EH, Bak RPM (1993) Effects of coral bleaching on tissue regeneration potential and colony survival. Mar Ecol Prog Ser 96:189-198

Meesters EH, Wesseling I, Bak RPM (1996) Partial mortality in three species of reef-building corals and the relation with colony morphology. Bull Mar Sci 58:838-852

Meesters EH, Wesseling I, Bak RPM (1997) Coral colony tissue damage in six species of reef-building corals: partial mortality in relation with depth and surface area. J Sea Res 37(1/2):131-144

Mumby PJ (1999) Bleaching and hurricane disturbances to populations of coral recruits in Belize. Mar Ecol Prog Ser 190:27-35

Nakamura T, Van Woesik R (2001) Water-flow rates and passive diffusion partially explain differential survival of corals during 1998 bleaching event. Mar Ecol Prog Ser 212:301-304

Nakamura T, Yamasaki H, Van Woesik R (2003) Water flow facilitates recovery from bleaching in the coral Stylophora pistillata. Mar Ecol Prog Ser 256:287-291

Normile D (2000) Some coral bouncing back from El Niño. Science 288:941-942

Nugues MM (2002) Impact of a coral disease outbreak on coral communities in St.Lucia: what and how much has been lost? Mar Ecol Prog Ser 229:61-71

Patterson MR (1992) A mass-transfer explanation of metabolic scaling relations in some aquatic invertebrates and algae. Science 255:1421-1423

Rosenberg E, Ben-Haim Y (2002) Microbial diseases of corals and global warming. Environ Microbiol 4(6):318-326

Sakai K (1998) Delayed maturation in the colonial coral Goniastrea aspera (Scleractinia): whole-colony mortality, colony growth and polyp egg production. Res Popul Ecol 40(3):287-292

Szmant AM, Gassman NJ (1990) The effects of prolonged bleaching on the tissue biomass and reproduction of the reef coral Montastrea annularis. Coral Reefs 8:217-224

Wilkinson CR (1999) Global and local threats to coral reef functioning and existence: review and predictions. Mar Freshw Res 50:867-878

Submitted: November 22, 2004; Accepted: March 15, 2005

Proofs received from author(s): May 12, 2005 